\title{
Amaranth Protein Improves Lipid Profile and Insulin Resistance in a Diet-induced Obese Mice Model
}

\author{
Abraham Escobedo-Moratilla, ${ }^{1, \#}$, Aida J. Velarde-Salcedo ${ }^{1, \#}$, Cynthia V. Magaña-Hernández ${ }^{1}$, \\ Alberto Barrera-Pacheco ${ }^{1}$, Eduardo Espitia-Rangel ${ }^{2}$, Alfredo Herrera-Estrella ${ }^{3}$, Ana P. Barba de la Rosa ${ }^{1, *}$ \\ ${ }^{1}$ IPICYT, Instituto Potosino de Investigación Científica y Tecnológica A.C. Camino a la Presa San José 2055, \\ Col. Lomas $4^{\text {a }}$ Sección, C.P. 78216, San Luis Potosí, Mexico \\ ${ }^{2}$ INIFAP, Instituto Nacional de Investigaciones Forestales Agrícolas y Pecuarias. Campo Experimental Valle de México, \\ Km 13.5 Carr Los Reyes-Texcoco,C.P. 56250 Texcoco Estado de México \\ ${ }^{3}$ Laboratorio Nacional de Genómica para la Biodiversidad, CINVESTAV-Irapuato, Irapuato, 36821, México \\ ${ }^{\#}$ These authors contributed equally to this work. \\ *Corresponding author: apbarba@ipicyt.edu.mx
}

\begin{abstract}
Amaranth has been claimed as functional food, but its function on obesity-related disorder is not fully known. The aim of this study was to analyse the effect of amaranth protein intake on blood lipids profile and insulin resistance in diet-induced obese mice. The effect of soybean protein was also analysed for comparative purposes. C57BL-6 mice were fed for eight weeks with regular or high fat diet. Amaranth or soybean protein isolates $(10 \mathrm{mg} / \mathrm{kg})$ were supplied via oral administration. Changes in body weight, adipose tissue, total cholesterol, triglycerides, insulin, a glucose tolerance test, as well as the expression of lipid metabolism-related genes were measured. Our results have shown that amaranth protein induces a decrease in plasma insulin in mice fed with a regular diet, whereas a decrease in triglycerides was observed in mice fed with high fat diet. Furthermore, down-regulation of Tnf- $\alpha$ and Res, suggested the inhibition of inflammation state. The present study demonstrates that amaranth protein, but not soybean protein, improves the obese mice health, and the hormonal modulation (Lep, Fasn, Lpl) could lead to new mechanism of action by which amaranth consumption exerts its beneficial health effect.
\end{abstract}

Keywords: amaranth, cytokines, insulin resistance, obesity, protein isolate, soybean

Cite This Article: Abraham Escobedo-Moratilla, Aida J. Velarde-Salcedo, Cynthia V. Magaña-Hernández, Alberto Barrera-Pacheco, Eduardo Espitia-Rangel, Alfredo Herrera-Estrella, and Ana P. Barba de la Rosa, "Amaranth Protein Improves Lipid Profile and Insulin Resistance in a Diet-induced Obese Mice Model." Journal of Food and Nutrition Research, vol. 5, no. 12 (2017): 914-924. doi: 10.12691/jfnr-5-12-6.

\section{Introduction}

Obesity and associated disorders are the main mortality causes affecting around 50\% of the worldwide population. The World Health Organization has established that biological, sociocultural and psychological factors are related with this epidemic; however an energy imbalance between consumed and expended calories is the most important factor that could triggers obesity [1]. Obesity can be prevented or treated following a balanced diet and physical activity. Furthermore, the regular intake of several foods containing one or more bioactive compounds could improve health or reduce the risk of obesity and its complications [2]. The interest on functional foods has increased due to several benefits in a diversity of illness [3]. Particularly, it has been reported that some seed protein isolates from soybean, barley, amaranth, quinoa, and linseed have a positive biological activity against several metabolic disorders, as shown in studies in disease models such as diet-induced obesity [4], streptozotocin-induced diabetes [5,6], proliferation of cancer cells [7] and alcohol-induced cirrhosis [8].

Several studies using in vitro and in vivo systems have shown that amaranth presents activity against high serum lipid levels, insulin resistance, and weight gain due to its content of fatty acids and squalene, protein and starch quality as reviewed elsewhere [9]. Reports have proposed that amaranth protein could be responsible of those effects, since bioactive peptides delivered after protease activity in stomach and intestine, are absorbed into the bloodstream [10]. A few reports have also indicated that amaranth contains peptides with inhibitory capacity against Dipeptidyl peptidase-IV (DPPIV), an incretin-degrading enzyme [11] and Angiotensin Converting Enzyme (ACE), a vasoconstriction-related enzyme [12]. Additionally, peptides with lipid-lowering [13] and antidiabetic activity have been reported [14]. However, the effect of the amaranth at a level of gene expression in adipose tissue has not been studied. Thus the aim of the present study was to evaluate whether an amaranth protein isolate, when administrated daily via oral, could improve the lipid and insulin resistance profile in diet-induced obese mice C57BL/6 model. 


\section{Materials and Methods}

\subsection{Protein Isolates}

Amaranth protein isolate (AMA) was prepared from Amaranthus hypochondriacus cv. Nutrisol seeds, which were obtained from the Amaranth germplasm collection of INIFAP (Campo Experimental Valle de Mexico, Texcoco Estado de Mexico). Soybean protein isolate (SOY) was prepared from Glycine Max seeds, which were purchased at a local market (San Luis Potosi, México). The method for both amaranth and soybean protein extraction consisted in an acid precipitation after alkaline extraction with some modifications $[15,16]$. Briefly, the seed flour was defatted with hexane $(1: 20)$ in constant stirring during 2 h. Defatted flour was recovered by centrifugation at $17,000 \mathrm{xg}$ for $30 \mathrm{~min}$, kept at room temperature until dryness, and then mixed with $10 \mathrm{mM}$ sodium carbonate buffer $\mathrm{pH} 10$ (1:20) for $2 \mathrm{~h}$ under constant stirring and centrifuged at $17,000 \mathrm{xg}$ for $30 \mathrm{~min}$ at room temperature. The supernatant was recovered and mixed with the appropriate amount of sodium citrate to reach a final concentration of $10 \mathrm{mM}$ and $\mathrm{pH}$ adjusted to 4.0 with concentrated hydrochloric acid. The resulting precipitate was recovered by centrifugation at $17,000 \mathrm{xg}$ for $30 \mathrm{~min}$ at room temperature. The final pellet was defatted again to ensure the absence of lipid components in the protein isolates. Pellets were mixed with acetone $(1: 10)$ centrifuged and dried as above and kept at room temperature until dryness.

\subsection{Protein Isolates Characterization}

Proximate analysis of protein isolates was carried out according to the Association of Official Agricultural Chemists Methods [17]. Nitrogen was determined as total nitrogen $(\mathrm{N})$ and converted to protein content multiplying by factor NX5.85 for AMA and NX5.77 for SOY.

Protein electrophoretic profiles were obtained under native, denaturing and reducing conditions. For native gels, protein samples $(10 \mu \mathrm{g})$ were separated in $4 \%$ native polyacrylamide gels. For denaturing conditions, 13.5\% sodium dodecyl sulfate-polyacrylamide gels (SDS-PAGE) were used and the reduction of disulfide bonds was performed by the addition of 2-mercaptoethanol (5\% v/v) to the protein samples and heated at $100{ }^{\circ} \mathrm{C}$ for $2 \mathrm{~min}$. Protein samples $(10 \mu \mathrm{g})$ were loaded to the gels and proteins separated using the Mini Protean III system (Bio-Rad Laboratories Inc., Hercules, CA, USA). Gels were stained with Coomassie Brilliant Blue G-250 and digitalized using a Gel Logic 100 system (Eastman Kodak Co., Rochester, NY, USA).

\subsection{Animals and Diets}

Animal experimental procedures were conducted according to Mexican regulation (NOM-062-ZOO-1999). The research protocol was approved by the Institutional Research Bioethics Committee - IPICYT, San Luis Potosi, México, with an approval code: LPBM-AMA-C57/002. Four to six-week-old male C57BL/6 mice were purchased from
Unidad de Producción y Experimentación de Animales de Laboratorio UPEAL (UAM Xochimilco, México). The animals were randomly selected to form 6 groups $(n=8$ per group). The regular diet (RD) groups received Teklad 2018S diet with $18 \%$ kcal from fat and the high fat diet (HF) groups received Teklad TD 06414 diet with 60.3\% kcal from fat (Envigo RMS S.A. de C.V., DF, México). The protein, carbohydrate and fat content, as well as energy density of diets are summarized in Table 1 . One control group was fed with regular diet for rodent chow (Ctrl-RD), the second control group was fed with high-fat diet (Ctrl-HF). The third group was fed with regular rodent chow administered with AMA protein (AMA-RD). The fourth group was the high-fat chow with AMA (AMA-HF). The fifth was the soybean group with regular rodent chow (SOY-RD) and the last one was the soybean group with high-fat diet (SOY-HF). Protein isolates were resuspended in phosphate buffered saline (PBS) pH 7.5 at a dose of $10 \mathrm{mg} / \mathrm{Kg}$ using an administration factor of 1 $\mathrm{ml} / \mathrm{Kg}$, in the case of control groups only PBS was administered. Protein isolates were administered once daily orally using a stainless steel oral gavage. Animals were housed under standard conditions (constant temperature of $21 \pm 2{ }^{\circ} \mathrm{C}$, with relative humidity of $50 \% \pm 15 \%$, and a $12 \mathrm{~h}$ light/dark cycle). Food and water were provided ad libitum. All treatments were administered during 8 weeks.

Table 1. Regular and high-fat diet composition

\begin{tabular}{|c|c|c|c|c|}
\hline \multirow{2}{*}{ Component } & \multicolumn{2}{|c|}{$\begin{array}{c}\begin{array}{c}\text { Regular diet 2018s } \\
(\%)\end{array} \\
\end{array}$} & \multicolumn{2}{|c|}{$\begin{array}{l}\text { High-fat diet TD.06414 } \\
\text { (\%) }\end{array}$} \\
\hline & g & kcal & g & kcal \\
\hline Total Protein & 18.6 & 24.0 & 23.5 & 18.4 \\
\hline Total Carbohydrate & 44.2 & 58.0 & 27.3 & 21.3 \\
\hline Total Fat & 6.2 & 18.0 & 34.3 & 60.3 \\
\hline Saturated Fat* & 14.5 & - & 37.0 & - \\
\hline Monunsaturated Fat* & 21.0 & - & 47.0 & - \\
\hline Polyunsaturated Fat* & 54.8 & - & 16.0 & - \\
\hline Energy density (kcal/g) & 3.1 & & 5.1 & \\
\hline
\end{tabular}

* \% of Total Fat.

\subsection{Physiological and Biochemical Determinations}

Body weight and the amount of food intake were recorded each week. One day before the end of the experiment, a glucose tolerance test was performed with a glucose dose of $2 \mathrm{mg} / \mathrm{kg}$ and a fasting period of $6 \mathrm{~h}$ using a FreeStyle glucometer (Abbott Diabetes Care, Almeda, CA, EUA), as described previously by Andrikopoulos et al. [18]. At the end of the experimental period mice were anesthetized, blood was collected by retro-orbital punction and the epididymal adipose tissue (EAT) was collected after euthanasia. Total blood cholesterol (CHO) and triglycerides (TG) were measured with an Accutrend Plus device (Roche Diagnostics GMBH, Mannheim, DE). Plasma insulin levels were determined using an ELISA kit following the supplier's instructions (ALPCO, Salem, MA, EUA). 


\subsection{Tissue RNA Extraction and Gene Expression Analysis by qRT-PCR}

Gene expression of key genes involved in lipid and carbohydrate metabolism were determined in the EAT by quantitative real-time PCR. EAT samples (200 mg) were used to extract the total RNA using TRIzol reagent (Life Technologies Corp., Carlsbad, CA, USA) according to the manufacturer's directions. RNA was dissolved in RNase-free water and quantified in a NanoDrop ND-1000 system (Thermo Fisher Scientific, Wilmington, DE, USA). RNAs (1500 ng) were denatured at $65{ }^{\circ} \mathrm{C}$ for $5 \mathrm{~min}$, at $4{ }^{\circ} \mathrm{C}$ for $5 \mathrm{~min}$ and then, reverse transcribed to obtain the cDNA using RevertAid reverse transcriptase (Thermo Fisher Scientific), CDS Primer and SMART II-A from the SMART PCR cDNA synthesis kit (Clontech Laboratories Inc., Mountain View, CA, USA). The cDNA synthesis reaction was carried out at $42^{\circ} \mathrm{C}$ for $120 \mathrm{~min}$ with a final step of $10 \mathrm{~min}$ at $70^{\circ} \mathrm{C}$ in a T100 Thermal Cycler (Bio-Rad). Individual qRT-PCRs were carried out with 50 ng of cDNA and using the POWER SYBER Green RNA-to- $\mathrm{C}_{\mathrm{T}}$ 1-step kit (Applied Bio-Systems, Foster City, CA, USA) according to the manufacturer's directions. Reactions were carried out in a CFX96 Touch real-time detection system (Bio-Rad). The primers for Lipoprotein Lipase (Lpl), Leptin (Lep), Resistin (Res), and Tumor Necrosis Factor-alfa (Tnf- $\alpha)$ were purchased from T4Oligo (ADN Sintético S.A.P.I. de C.V, Irapuato, Gto, México). Primers for Adiponectin (Adpn), Acid Binding Protein 4 (Fabp4) and ribosomal 18S (18s) were purchased from Sigma-Aldrich (Sigma-Aldrich Química, S. de RL. de CV., Toluca, Méx, México). The primers sequences are listed in Supplementary Table S1. The resulting values were normalized with respect to the constitutive $18 S$ gene. For the statistical analysis, the Ctrl$\mathrm{RD}$ group normalized value was considered as $100 \%$ of the response. A heat-map was generated with the same software for gene clustering according to the similarity of their expression profile.

\subsection{Statistical Analysis}

For body weight measurements, the sample size was calculated assuming a minimum detectable difference of $30 \%{ }^{[18]}$, a desired statistical power of 0.8 , and an alpha error of 0.05 for an ANOVA analysis using the sample size calculator from SigmaPlot 12.3 software (Systat Inc., Chicago, IL, USA). The statistical analysis was performed through a one-way analysis or a two-way analysis (in the case of time course of blood glucose) of variance (ANOVA) with a Holm-Sidak post-hoc test using the analysis tool from SigmaPlot 12.3 software (Systat Inc., Chicago, IL, USA). All data were expressed as the mean \pm standard error (SE). Significance was considered if $p<0.05$. Pearson's correlation coefficient was determined using the same software for evaluate the correlations between gene expression and physiological and biochemical parameters. A Principal Component Analysis (PCA) was performed using XLSTAT software (Addinsoft, Paris, France) to investigate the relationships between analyzed variables. All the variables were included in the analysis that was based on the Pearson's correlation matrix (12 variables).
A principal component was considered significant if it squared cosines were $>0.5$.

\section{Results}

\subsection{Protein Isolates Characterization}

The protein isolates from AMA and SOY contained $81.8 \%$ and $85.5 \%$ protein, respectively (Table 2). The electrophoretic profile under native conditions showed a main band of $500 \mathrm{kDa}$ in AMA isolates, while two bands of (600 and $700 \mathrm{kDa}$ ) were observed in SOY isolates (Figure 1A). Under denaturant conditions bands at $60 \mathrm{kDa}$ and $38 \mathrm{kDa}$ were observed in AMA, while bands at 60, 50 and $28 \mathrm{kDa}$ were observed in SOY isolates (Figure 1B). Under denaturant and reducing conditions, AMA isolates showed the formation of two groups of bands (17-24 kDa and 30-35 kDa), which are characteristics of the basic and acidic subunits of $11 \mathrm{~S}$ globulins. In SOY isolates the acidic and basic subunits were also observed as well the bands at 50 and $90 \mathrm{kDa}$ (Figure 1C).

Table 2. Proximal composition of AMA and SOY protein isolates ${ }^{\mathrm{a}}$

\begin{tabular}{ccc}
\hline \multirow{2}{*}{ Component } & \multicolumn{2}{c}{ Content (\%) } \\
\cline { 2 - 3 } & Amaranth & Soybean \\
\hline Fat & 0.94 & 1.11 \\
Protein & $81.8^{\mathrm{b}}$ & $85.5^{\mathrm{c}}$ \\
Others $^{\mathrm{d}}$ & 22.5 & 13.4 \\
\hline
\end{tabular}

${ }^{\mathrm{a}}$ Reported as \%(db). ${ }^{\mathrm{b}} \mathrm{Nx} 5.8 .{ }^{\mathrm{c}} \mathrm{Nx} 5.77 .{ }^{\mathrm{d}}$ Determined as difference including ashes and sugars.

These results are in agreement with the globulins structure, $11 \mathrm{~S}$ globulins are hexameric molecules involving two trimers with molecular weights of 300-400 $\mathrm{kDa}$, each trimer is formed by $50-60 \mathrm{kDa}$ monomers conformed by two subunits of 25 and $35 \mathrm{kDa}$ joined by disulphide bonds. The 7S proteins are conformed by 40-70 $\mathrm{kDa}$ monomers, which are not affected by reducing conditions [19]. The electrophoretic profile indicates that in amaranth, the $11 \mathrm{~S}$ globulins is the main component as reported before [20], while both 7S and 11S globulins make up to $80 \%$ of total protein in soybean [21]. Although at structural level, $11 \mathrm{~S}$ globulins are similar, $11 \mathrm{~S}$ globulins from amaranth shared only 43.05\% homology with $11 \mathrm{~S}$ from soybean, while 11S globulins and 7S globulins share $22.4 \%$ homology. It is noteworthy to mention that the balance of essential amino acids (Met, Ile, Leu, His, Thr, Trp, Val, Lys, Phe), is better represented in amaranth than in soybean proteins, specially amaranth has higher methionine contents than soybean.

\subsection{Mice Body Weight and Adipose Tissue Content}

To estimate the change in the mice body weight throughout the experiment, the percentage of the weight difference between initial and final values was calculated. A clear difference between the Ctrl-RD and Ctrl-HF was obtained $(\sim 25 \%)$ indicating the successful induction of 
weight gain by the diet. However, the SOY-RD group showed a significant tendency to weight gain (Figure 2A). In order to verify if the observed weight gain occurred as a consequence of an increment in adipose tissue, the EAT was measured. As expected, the increment of body weight correlated with EAT accumulation (Figure 2B).

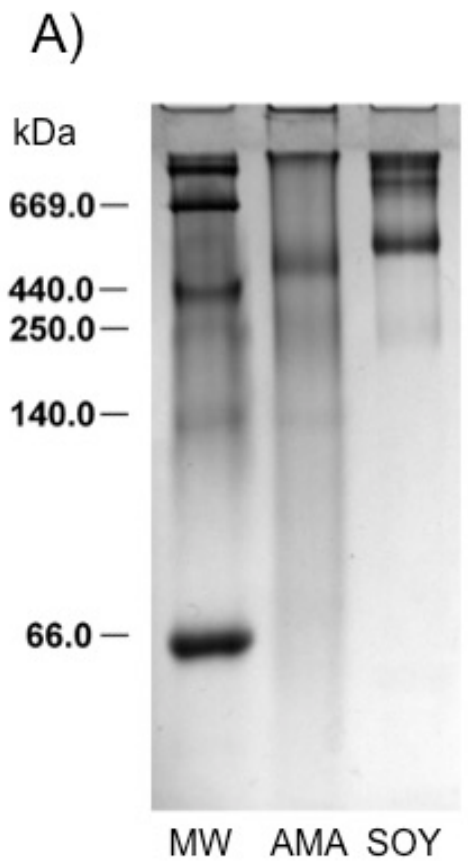

B)

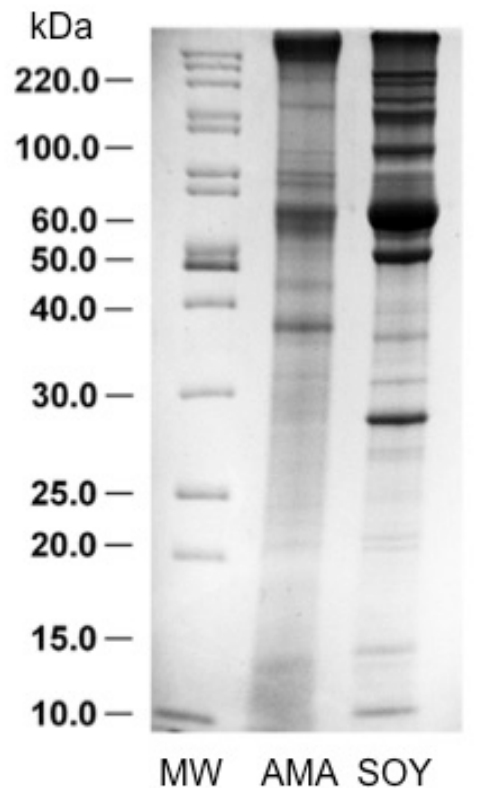

C)

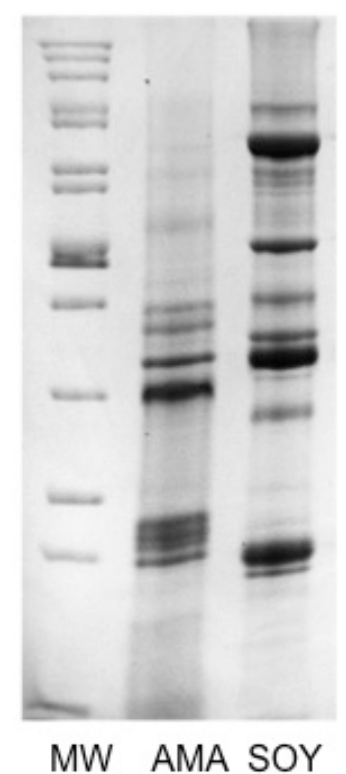

Figure 1. Protein electrophoretic patterns from amaranth and soybean isolates. Proteins were analysed under: A) native, B) denaturing non-reducing, and $\mathrm{C}$ ) denaturing and reducing conditions. MW=molecular weight standard; AMA= amaranth protein isolate; SOY=soybean protein isolates
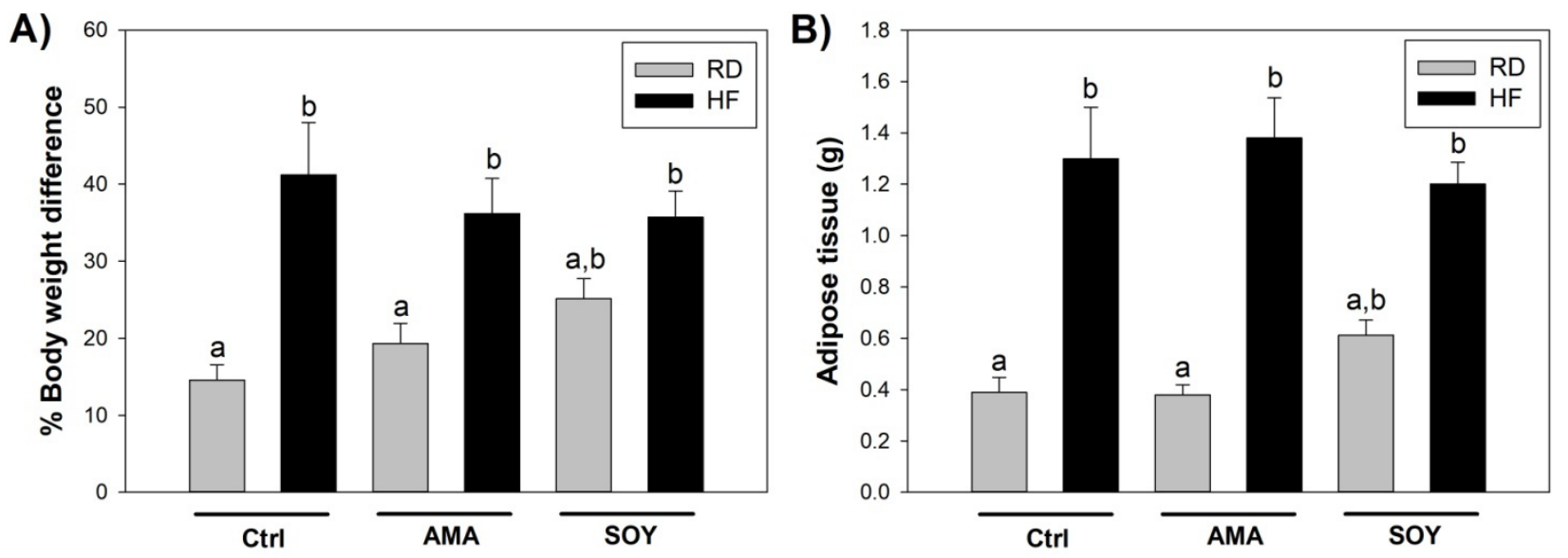

Figure 2. A) Percentage of mice body weight gain. B) Epididymal Adipose Tissue (EAT) after eight weeks of treatment. Values are the mean of triplicates \pm SE $(n=8)$. Different letters indicate statistical differences among groups at $p<0.05$. RD=regular diet; HF=High fat diet; Ctrl=control diet; $\mathrm{AMA}=$ amaranth protein isolate; $\mathrm{SOY}=$ soy protein isolates

Table 3. Lipids profile, glucose_AUC and insulin levels in mice blood after eight weeks of AMA and SOY proteins intake

\begin{tabular}{|c|c|c|c|c|}
\hline Group & $\begin{array}{c}\text { Cholesterol } \\
(\mathrm{mg} / \mathrm{dl})\end{array}$ & $\begin{array}{c}\begin{array}{c}\text { Triglycerides } \\
(\mathrm{mg} / \mathrm{dl})\end{array} \\
\end{array}$ & $\begin{array}{c}\begin{array}{c}\text { Glucose_AUC } \\
(\mathrm{mg} / \mathrm{dl})\end{array} \\
\end{array}$ & $\begin{array}{l}\text { Insulin } \\
\text { (ng/ml) }\end{array}$ \\
\hline Ctrl-RD & $162.9^{c} \quad \pm 1.60$ & $102.4^{\mathrm{e}} \pm 3.68$ & $22005^{\mathrm{b}} \pm 417.1$ & $0.39^{c} \pm 0.03$ \\
\hline Ctrl-HF & $168.5^{\mathrm{b}} \pm 0.94$ & $144.0^{\mathrm{c}} \pm 4.60$ & $29943^{\mathrm{a}} \pm 1514.0$ & $0.42^{\mathrm{c}} \pm 0.07$ \\
\hline AMA-RD & $167.2^{\mathrm{b}, \mathrm{c}} \pm 1.24$ & $116.0^{\mathrm{d}} \pm 5.61$ & $20826^{\mathrm{b}} \pm 346.4$ & $0.09^{\mathrm{d}} \pm 0.01$ \\
\hline AMA-HF & $167.4^{\mathrm{b}, \mathrm{c}} \pm 0.73$ & $125.1^{\mathrm{c}, \mathrm{d}} \pm 4.82$ & $29728^{\mathrm{a}} \pm 1507.6$ & $0.32^{\mathrm{c}} \pm 0.07$ \\
\hline SOY-RD & $166.0^{\mathrm{b}, \mathrm{c}} \pm 1.59$ & $158.2^{\mathrm{b}, \mathrm{c}} \pm 14.5$ & $21495^{\mathrm{b}} \pm 800.1$ & $0.95^{\mathrm{a}} \pm 0.19$ \\
\hline SOY-HF & $172.9^{\mathrm{a}} \pm 0.95$ & $178.3^{\mathrm{a}} \pm 11.0$ & $27437^{\mathrm{a}} \quad \pm 1752.7$ & $0.61^{\mathrm{a}, \mathrm{b}} \pm 0.08$ \\
\hline
\end{tabular}

AUC=Area under the curve from Figure 3. Ctrl-RD=Control group with regular rodent diet;

$\mathrm{Ctrl}-\mathrm{HF}=\mathrm{Control}$ group with high-fat diet; AMA-RD=Amaranth group with regular rodent diet;

AMA-HF=Amaranth group with high-fat diet; SOY-RD=Soybean group with regular rodent diet;

SOY-HF=Soybean group with high-fat diet. Mean \pm standard error. Different superscript letters in the same column indicate statistically differences among groups $(p<0.05)$. 


\subsection{Lipid and Insulin Resistance Profiles}

As shown in Table 3, the HF diet increased the $\mathrm{CHO}$ and TG levels in control and SOY diets. Interestingly, differences in these parameters were not detected when AMA protein was supplied in the diet. On the other hand, the combination of HF diet with SOY protein induced a statistically significant increase in CHO and TG levels.

In order to explore the insulin resistance state among the different groups, at the end of the experiment a glucose tolerance test was carried out. The glucose tolerance test showed a higher level of blood glucose in HF groups independently of the treatment except at time 0 and at $120 \mathrm{~min}$ (Figure 3). At time $30 \mathrm{~min}$ Ctrl-HF and SOY-HF groups had a significant difference, however, when the time courses were converted to area under the curve (AUC), no significant differences were detected among RD neither among HF diet (Table 3).

Furthermore, to confirm the presence of insulin resistance, plasma insulin levels were quantified. As noted in Table 3, Ctrl-RD and Ctrl-HF did not show differences in plasma insulin concentrations (0.39 and $0.42 \mathrm{ng} / \mathrm{ml}$, respectively). AMA-RD showed the lowest values (0.09 ng/mL), while AMA-HF insulin values $(0.32 \mathrm{ng} / \mathrm{ml})$ were similar as Ctrl-RD diets. SOY groups had the highest insulin concentration ( 0.61 to $0.95 \mathrm{ng} / \mathrm{ml})$. This is interesting because SOY diets required ten times more insulin than AMA diets to arrive to the same glucose levels.

\subsection{Gene Expression Profiles}

Analysis of the expression of selected genes resulted in the expected increase when comparing an HF diet with respect to the Ctrl groups (Figure 4). However, different responses were appreciated when comparing AMA with SOY treatments. According to the expression profiles, the tested genes were grouped into two clusters. The cluster I grouped the Res, Lpl, Adpn, while the cluster II grouped Tnf- $\alpha$, Fasn, Lep and Fabp4 (Figure 5). Interestingly, the addition of AMA to the HF diet resulted in the same behaviour as Ctrl-diets, however SOY-HF resulted in an upregulation of cluster 1 . By other hand, the addition of AMA in $\mathrm{HF}$ had better response to down-regulate the genes of cluster II as compared to the Ctrl-HF diets.

\subsection{Principal Component Analysis (PCA) and Pearson's Correlations}

The PCA is an exploratory tool to propose associations when several variables are evaluated. A PCA analysis was performed to explore the distributions and possible associations among all the variables tested in the present study. Supplementary Table S2 shows that F1 (Principal Component 1) had the highest loading values in all the analysed variables, except for insulin for which the highest loading value was detected in F3. The plot in Figure 6A shows that F1 and F2 defined the projection of all the measured variables in $81.76 \%$, positioning the treatment groups in different places around axes. AMA diets are in close association with Ctrl diets being AMA-RD and Ctrl-RD very close grouped, while SOY diets are very distant. More interesting, the AMA-HF diet was located in the middle of the graphic. Figure 6B shows all the variables included in the present study; all of them, except insulin are explained by F1, however no negative correlations were appreciated. Potentially, variables on the left and right of the plot are correlated, however when correlation analysis was carried on, only statistically significant correlations were detected among CHO concentrations with Lpl, Adpn, and Res (Supplementary Table S3 and Supplementary Figure S1).

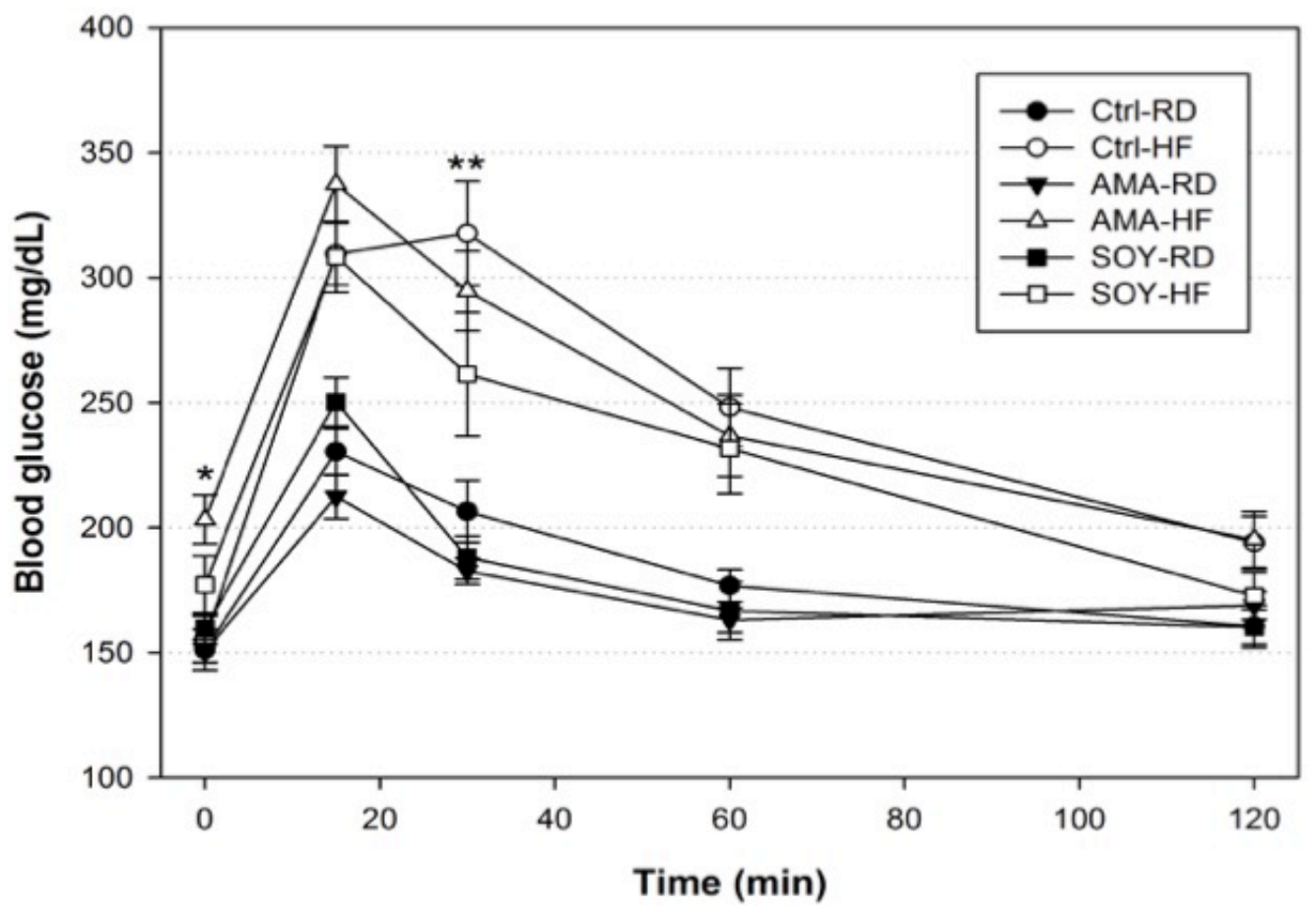

Figure 3. Mice glucose tolerance-time course test, after 8 weeks of consumption of protein isolate. Each graphic-point represents the mean of triplicates \pm SEM $(n=8-10)$. One star $(p<0.05)$ represents differences among groups: AMA-HF vs. AMA-RD; AMA-HF vs. Ctrl-RD. Two stars $(p<0.05)$ represents differences between Ctrl-HF vs. SOY-HF 

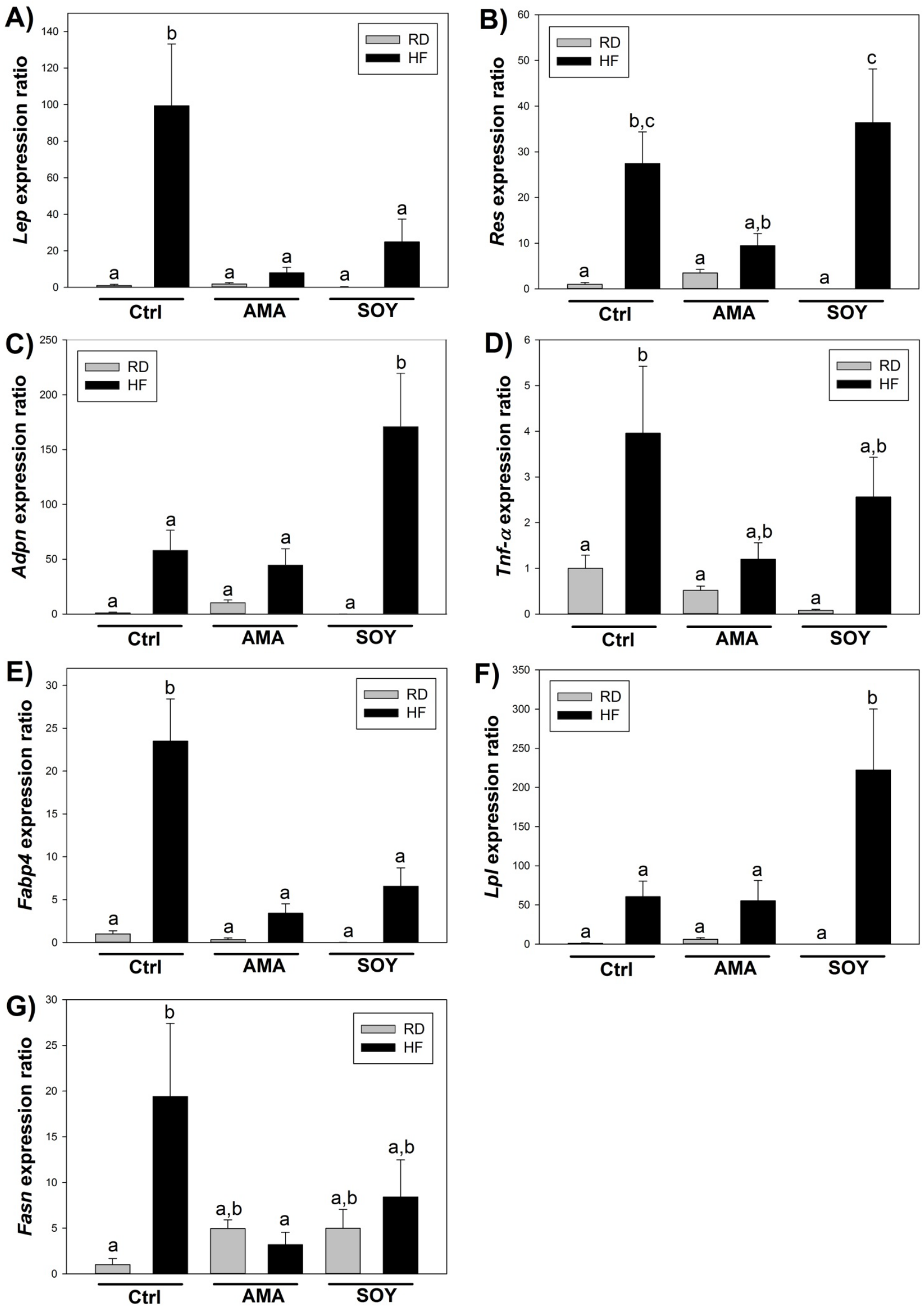

Figure 4. Relative expression of some genes expressed in mice adipose tissue after 8 weeks of treatment. Bars represent the mean of triplicates \pm SE $(n=8)$. A=Lep, B=Res, C=Adpn, $\mathrm{D}=$ Tnf- $\alpha, \mathrm{E}=$ Fabp4, $F=L p l, G=$ Fasn. The amplification of $18 \mathrm{~s}$ was used as control. Different letters indicate statistical differences among groups at $p<0.05$. $\mathrm{RD}=$ regular diet; $\mathrm{HF}=\mathrm{High}$ fat diet; $\mathrm{Ctrl}=$ control diet; $\mathrm{AMA}=$ amaranth protein isolate; $\mathrm{SOY}=$ soy protein isolates 


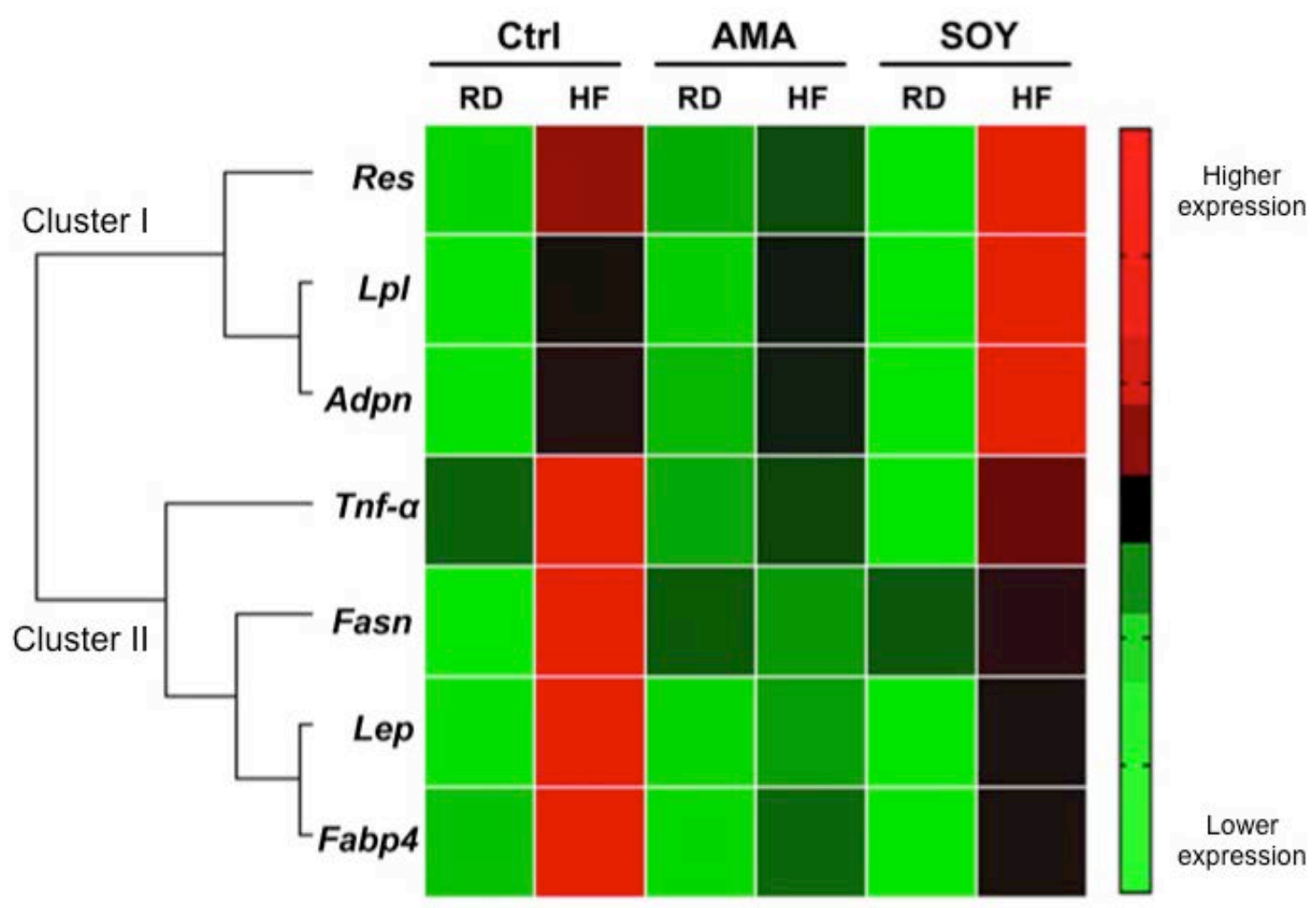

Figure 5. Heat-map of the mRNA expression levels. Genes have been grouped according to the similarity of the expression profile between groups. The colour of the squares indicates the levels of expression; red is the highest and green the lowest level. $\mathrm{RD}=$ regular diet; $\mathrm{HF}=\mathrm{High}$ fat diet; Ctrl=control diet; $\mathrm{AMA}=$ amaranth protein isolate; $\mathrm{SOY}=$ soy protein isolates

A)

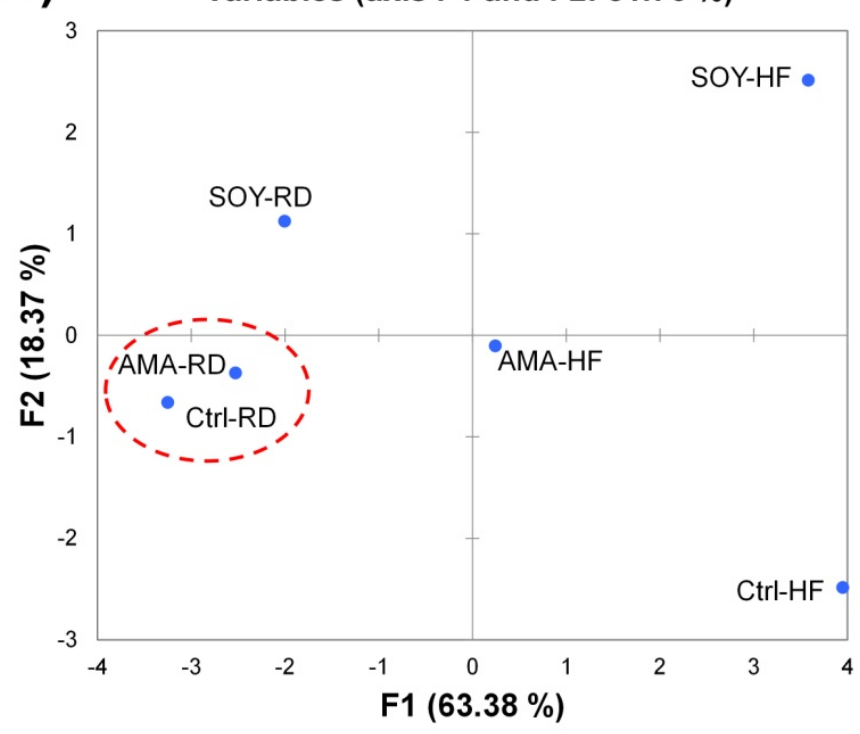

B)

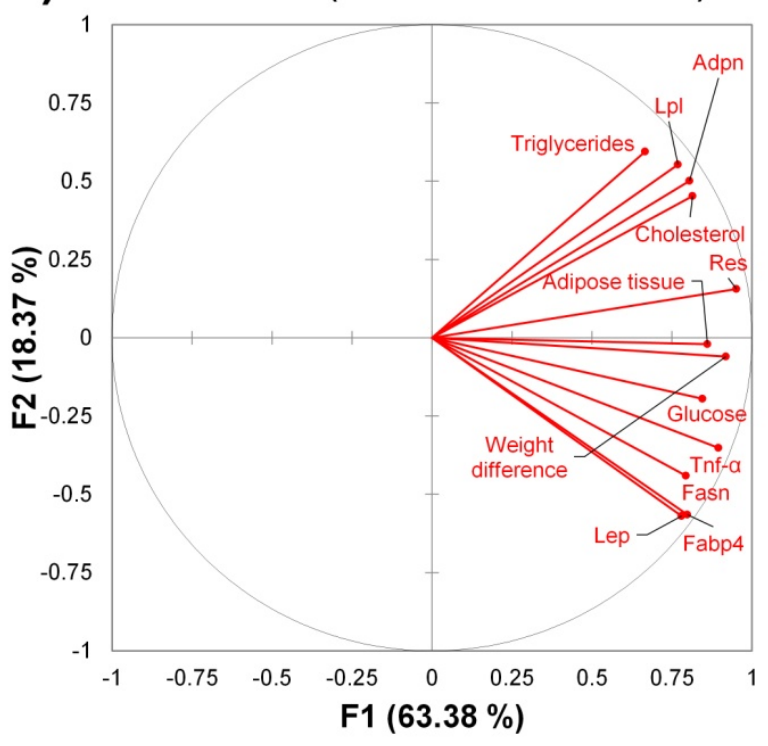

Figure 6. A) PCA score plot of the analyzed groups. B) Projection of the variables evaluated in the plane defined by the two first principal components

\section{Discussion}

Amaranth has been claimed as a functional food, but its function on obesity-related disorder is still not clear. Several studies have shown that the amaranth consumption as popped seeds, flour or oil, has beneficial effects on health, but only few reports have focused on the therapeutic effect of amaranth protein isolates. It has been reported that hamsters feed with amaranth protein was observed a $27 \%$ of hypercholesterolemia reduction, but when amaranth was administered in the presence of casein the observed reduction reached the $48 \%$ [22]. It was also reported that treated Wistar rats with $2.5 \%(\mathrm{w} / \mathrm{w})$ of a protein isolate of Amaranthus mantegazzianus had a significant decrease in the plasma levels of CHO, TG, and oxidation when compared with control rats [23]. However, until date, no studies have been reported on the influence of amaranth on regulation of hormone profiles.

Soybean is one of the most marketed legumes in the world due to its high protein content and non-complex production [24]. The notable effects of the oil and hormone-like molecules of soybean have been studied in 
depth, but protein isolates for the treatment of obesity and related disorders only include the fatty acid metabolism [25], bone structure improvement [26], and steatosis models [27]. On the other hand, several studies have indicated that soybean protein consumption limits the body fat accumulation, improves insulin resistance and reduces plasma lipids [28]. Then, soybean is a good reference protein to compare with the effects produced by consumption of amaranth proteins.

One of the main results found in the present study was the inability of the both AMA and SOY protein isolates to prevent the weight increase and accumulation of adipose tissue in HF-diets. This indicates that these protein isolates supplied at $10 \mathrm{mg} / \mathrm{kg}$ are not enough to exert a significant effect on body weight reduction. But this was expected because the levels of proteins used are only considered as to supply a source of bioactive compounds, then this trail is not considered as a high protein rich diet supplementation, which is associated with body weight loss [29]. However because the amount of protein administered is not considered as a HP-diet, it also does not causes the problems of health deterioration as reported recently [30]. But most important, it has been described that the type of protein could have different effects on body weight [31]. In this sense, AMA protein had the ability to maintain the $\mathrm{CHO}$ and TG at the same levels of Ctrl diets (Table 3) while SOY treatment produced a rise of $\mathrm{CHO}$ and TG levels and the only difference between the AMA and SOY protein isolates is their amino acid composition. Gorinstein et al. [32] reported that SOY has a higher content of branched chain amino acids (BCAAs) such as leucine, isoleucine, and valine and recent reports have shown that BCAAs have an important role in adipocyte metabolism, which could impact in lipogenesis and adipose tissue accumulation, as well as in type 2 diabetes [33,34]. Moreover, it is well known that amaranth proteins contains a better balance of essential amino acids, especially amaranth globulins contains higher amount methionine than soybean proteins.

The second finding was that although all groups presented the same glucose levels, AMA insulin levels were lower than the Ctrl groups in both RD and HF diets, but in the SOY protein amended diet two-fold higher insulin levels were observed, indicating a deficient processing of carbohydrates or and increased insulin resistance that leads to the development of type 2 diabetes.

The expression of four cytokines was evaluated: Res, Adpn, Tnf- $\alpha$ and Lep. Our results showed and up-regulation of Res in Ctrl-HF but higher values were observed in SOY-HF diets (Figure 5). AMA consumption allowed reverting the levels of Res observed in Ctrl-HF diets. It has been proposed that Res is a key molecule related with obesity and insulin resistance and both could indirectly contribute to the type 2 diabetes development [35]. This relationship could be explained by the intervention of Res in TLR4-dependent pathway, which ends in phosphorylation of I $\kappa \mathrm{B} \alpha$ and activation of transcription factors of several cytokines as recently reported [36]. Adpn, which modulates mainly glucose metabolism and fatty acid oxidation showed up-regulated in SOY-HF diet (Figure 5). This result is in accordance with the insulin resistance observed in SOY-HF group (Table 3). Tnf- $\alpha$ has been associated with chronic inflammation and as a link between obesity and type 2 diabetes [37,38]. As observed in Figure 5, Tnf- $\alpha$ was up-regulated in Ctrl-HF and SOY-HF diets but not in AMA diets, suggesting that AMA consumption has an important role in the inhibition of inflammation state, because Tnf- $\alpha$ is one of the most important inflammation markers which is increased in obesity state [38].

Lep, is an hormone mainly produced in adipose tissue, which regulates the energy balance inhibiting the appetite. But according to the type of diet and obesity grade, it has been reported that Lep can increase and generate Leptolerance [39]. Insulin has been reported as responsible of the increased production of Lep by an enhancement of glucose utilization by adipocytes. In the present study, no association was found between insulin accumulation and Lep expression. However, Ctrl-HF diets induced an upregulation of Lep, which was reverted at Ctrl levels by AMA diets. McManus et al. [40] reported that when C57BL/6 were fed with HF diet, Lep levels are lower when bovine serum albumin was added to the diet. This result suggests that AMA protein consumption can revert the Lep resistance caused by HF diets.

Fasn product is an enzyme that catalyses mainly the synthesis of palmitate from acetyl-CoA. The downregulation of Fasn in rodents adipose tissue has been reported when fat is supplemented in the diet, resulting in a decrease in the de novo fatty acid synthesis [41]. In the present study, the levels of Fasn mRNA were higher in Ctrl-HF than Ctrl-RD group, however AMA proteins had better effect on reduction of Fasn expression than SOY protein.

The product of Fabp4 facilitates the solubility of fatty acids in cytosol, therefore the role of this protein is crucial to normal adipocyte function. It has been reported that knockout mice with null Fabp4 expression had an increase of EAT mass [42]. Moreover, the fatty acids solubility could trigger other routes that are related with the Lep role [43].

In obese rodents and humans, it was observed the upregulation of $\mathrm{Lpl}$, in adipose tissue; however, high insulin levels seem to decrease its expression [42]. In the present study, the SOY-RD group showed the highest levels of insulin among all groups. High insulin levels, high concentration of TG, and the low response of $\mathrm{Lpl}$ could confirm that SOY protein has a negative effect in regulation of TG, when is administered with a HF diet. In contrast, the AMA protein had the opposite effect showing lower levels of insulin, lower TG, and expression level of Lpl are similar to Ctrl-diets (Figure 5).

\section{Conclusions}

Our findings suggest that the AMA protein administered at $10 \mathrm{mg} / \mathrm{Kg}$ in mice could modulate the reduction of the plasma insulin levels in RD group and the reduction of the TG levels in HF group. In the specific case of insulin lower levels, the glucose tolerance test confirmed that the carbohydrate metabolism remains efficient. By contrast, SOY produces the opposite effect, even when animals were fed with RD. This is the first work analysing the changes on gene expression profile on adipose tissue due to amaranth consumption. Our results have shown that the mechanism of action of the AMA protein involves the 
sensibilization of insulin pathway probably mediated by Lep down-regulation, the decrease of TG triggered by Fabp4 and Fasn down-regulation, and reversion of inflammation state as consequence of Tnf- $\alpha$ and Res down-regulation. All the gene expression profiles as well as physiological and biochemical parameters together with the PCA analysis indicates the close relationship between AMA and Ctrl-RD, so the AMA protein could be a potential improvement therapy in obesity-related disorders.

\section{Acknowledgments}

AEM thanks to the PhD fellowship (no. 265987), AJVS has a posdoctoral fellowship project Problemas Nacionales (no. 248415) and CVMH has a BSc. Fellowship (Asistentes de Investigación SNI) from CONACYT. AEM thanks E. Bojórquez-Velázquez for his technical assistance. We thank to Laboratorio de Investigación Molecular en Nutrición (LIMON)-Universidad del Centro de Mexico. This work was supported by IPICYT Entrepreneurial Program and Problemas Nacionales “Amaranto en la Soberanía Alimentaria No. 248415 (2015).

\section{Statement of Conflict of Interest}

The authors declare no conflict of interest

\section{References}

[1] WHO. World Health Organization. Obesity and Overweight. http://www.who.int/mediacentre/factsheets/fs311/en/. [Accessed May. 31, 2017).

[2] Majumder, K., Mine, Y. and Wu, J.P, "The potential of food protein-derived anti-inflammatory peptides against various chronic inflammatory disease," Journal of the Science of Food and Agriculture, 9(7)6. 2303-2311. May. 2016.

[3] Siro, I., Kapolna, E., Kapolna, B. and Lugasi, A, "Functional food. Product development, marketing and consumer acceptance--a review,” Appetite, 51(3). 456-467. Nov. 2008.

[4] Wanezaki, S., Tachibana, N., Nagata, M., Saito, S., Nagao, K., Yanagita, T. and Kohno, M, "Soy $\beta$-conglycinin improves obesity-induced metabolic abnormalities in a rat model of nonalcoholic fatty liver disease," Obesity Research \& Clinical Practice, 9(2). 168-174. Apr. 2015.

[5] Haliga, R., Mocanu, V., Oboroceanu, T., Stitt, P.A. and Luca, V.C, "The effects of dietary flaxseed supplementation on lipid metabolism in streptozotocin-induced diabetic hamsters," Revista Medico-Chirurgicala a Societatii de Medici Si Naturalisti Din Iasi, 111(2). 472-476. Apr/Jun. 2007.

[6] Yeh, W.J., Yang, H.Y. and Chen, J.R, Soy $\beta$-conglycinin retards progression of diabetic nephropathy via modulating the insulin sensitivity and angiotensin-converting enzyme activity in rats fed with high salt diet," Food and Function, 5(11). 2898-2904. Nov. 2014.

[7] Robles-Ramirez, M.C., Ramon-Gallegos, E., Reyes-Duarte, F.J. and Mora-Escobedo, R, "Effect of germinated soy protein on the growth of HeLa cervical cancer cells in female athymic mice," Nutrition Cancer, 64(8). 1261-1268. 2012.

[8] Yang, H.Y., Tzeng, Y.H., Chai, C.Y., Hsieh, A.T., Chen, J.R., Chang, L.S. and Yang, S.S, "Soy protein retards the progression of non-alcoholic steatohepatitis via improvement of insulin resistance and steatosis,” Nutrition, 27(9). 943-948. Sep. 2011.

[9] Huerta-Ocampo, J.A, and Barba de la Rosa, A.P, "Amaranth: A pseudo-cereal with nutraceutical properties," Current Nutrition \& Food Science, 7(1). Feb. 1-9, 2011.

[10] Dia, V.P., Torres, S., De Lumen, B.O., Erdman, J.W. and González de Mejia, E, "Presence of lunasin in plasma of men after soy protein consumption," Journal of Agricultural and Food Chemistry, 57(4). 1260-1266. Feb. 2009.

[11] Velarde-Salcedo, A.J., Barrera-Pacheco, A., Lara-Gonzalez, S., Montero-Moran, G.M., Diaz-Gois, A., Gonzalez de Mejia, E. and Barba de la Rosa, A.P, "In vitro inhibition of dipeptidyl peptidase IV by peptides derived from the hydrolysis of amaranth (Amaranthus hypochondriacus L.) proteins,” Food Chemistry, 136(2). 758-764. Jan. 2013.

[12] Barba de la Rosa, A.P., Montoya, A.B., Martinez-Cuevas, P., Hernandez-Ledesma, B., Leon-Galvan, M.F., De Leon-Rodriguez, A. and Gonzalez, C, "Tryptic amaranth glutelin digests induce endothelial nitric oxide production through inhibition of ACE: antihypertensive role of amaranth peptides," Nitric Oxide, 23(2):106-111. Sep. 2010.

[13] Kim, H.K., Kim, M.J., Cho, H.Y., Kim, E.K. and Shin, D.H, "Antioxidative and anti-diabetic effects of amaranth (Amaranthus esculantus) in streptozotocin-induced diabetic rats," Cell Biochemistry and Function, 24(3). 195-199. May/Jun. 2006.

[14] Kim, H.K., Kim, M.J. and Shin, D.H, "Improvement of lipid profile by amaranth (Amaranthus esculantus) supplementation in streptozotocin-induced diabetic rats," Annals of Nutrition and Metabolism, 50(3). 277-281. Feb. 2006.

[15] Areas, J.A. and Lawrie, R.A, "Effect of lipid-protein interactions on extrusion of offal protein isolates,” Meat Science, 11(4). 275299. 1984.

[16] Martinez, E.N. and Anon, M.C, "Composition and structural characterization of amaranth protein isolates. An electrophoretic and calorimetric study,” Journal of Agricultural and Food Chemistry, 44(9). 2523-2530. Sep. 1996.

[17] AOAC, "Official Methods of Analysis," Association of Official Analytical Chemists, Washington, D.C. 18th edn. 2007.

[18] Andrikopoulos, S., Blair, A.R., Deluca, N., Fam, B.C. and Proietto, $\mathrm{J}$, "Evaluating the glucose tolerance test in mice," American Journal of Physiology- Endocrinology and Metabolism, 295(6). E1323-1332. Dec. 2008.

[19] Utsumi, S, "Plant food protein engineering," Advances in Food Nutrition and Research, 36. 89-208. 1992.

[20] Barba de la Rosa, A.P., Paredes-López, O. and Gueguen, J, "Characterization of amaranth globulins by ultracentrifugation and chromatographic techniques," Journal of Agricultural and Food Chemistry, 40. 937-40. 1992.

[21] Yang, A., Yu, X., Zheng, A. and James, A.T, "Rebalance between $7 \mathrm{~S}$ and $11 \mathrm{~S}$ globulins in soybean seeds of differing protein content and 11SA4," Food Chemistry, 210(1). 148-155. Nov. 2016.

[22] Mendonça, S., Saldiva, P.H., Cruz, R.J. and Areas, J.A.G, "Amaranth protein presents cholesterol-lowering effect," Food Chemistry, 116(3). 738-742. Oct. 2009.

[23] Lado, M.B., Burini, J., Rinaldi, G., Anon, M.C. and Tironi, V.A, "Effects of the dietary addition of amaranth (Amaranthus mantegazzianus) protein isolate on antioxidant status, lipid profiles and blood pressure of rats," Plant Foods for Human Nutrition, 70(4). 371-379. Dec. 2015.

[24] Imai, S, "Soybean and processed soy foods ingredients, and their role in cardiometabolic risk prevention," Recent Patents on Food, Nutrition \& Agriculture, 7(2). 75-82. 2015.

[25] Eller, L.K. and Reimer, R.A, "A high calcium, skim milk powder diet results in a lower fat mass in male, energy-restricted, obese rats more than a low calcium, casein, or soy protein diet," Journal of Nutrition, 140(7). 1234-1241. Jul. 2010.

[26] Yan, L., Graef, G.L., Nielsen, F.H., Johnson, L.K. and Cao, J, "Soy protein is beneficial but high-fat diet and voluntary running are detrimental to bone structure in mice," Nutrition Research, 35(6). 523-31. Jun. 2015.

[27] Hakkak, R., Zeng, H., Dhakal, I.B. and Korourian, S, "Short- and long-term soy diet versus casein protects liver steatosis independent of the arginine content," Journal of Medicinal Food, 18(11). 1274-1280. Nov. 2015.

[28] Velasquez, M.T. and Bhathena, S.J, "Role of dietary soy protein in obesity," International Journal of Medical Science, 4(2). 72-82. 2007.

[29] Clifton, P, "Effects of a high protein diet on body weight and comorbidities associated with obesity," British Journal of Nutrition, 108(S2). S122-129. Aug. 2012.

[30] Diaz-Rúa, R., Keijer, J., Palou, A., van Schothorst, E.M. and Oliver, P, "Long-term intake of a high-protein diet increases liver triacylglycerol deposition pathways and hepatic signs of injury in rats,” Journal of Nutrition Biochemistry, 46. 39-48. Aug. 2017. 
[31] Liisberg, U., Myrmel, L.S., Fjaere, E., Ronnevik, A.K., Bjelland, S., Fauske, K.R., Holm, J.B., Basse, A.L., Hansen, J.B., Liaset, B., Kristiansen, K. and Madsen, L, "The protein source determines the potential of high protein diets to attenuate obesity development in C57BL/6J mice,” Adipocyte, 5(2). 196-211. Mar. 2016.

[32] Gorinstein, S., Delgado-Licon, E., Pawelzik, E., Permady, H.H., Weisz, M, and Trakhtenberg, S, "Characterization of soluble amaranth and soybean proteins based on fluorescence, hydrophobicity, electrophoresis, amino acid analysis, circular dichroism, and differential scanning calorimetry measurements," Journal of Agricultural and Food Chemistry, 49(11). 5595-5601. Nov. 2001.

[33] Chen, X, and Yang, W, "Branched-chain amino acids and the association with type 2 diabetes," Journal of Diabetes Investigation, 6(4). 369-370. Jul. 2015.

[34] Green, C.R., Wallace, M., Divakaruni, A.S., Phillips, S.A., Murphy, A.N., Ciaraldi, T.P, and Metallo, C.M, "Branched-chain amino acid catabolism fuels adipocyte differentiation and lipogenesis,” Nature Chemical Biology, 12(1). 15-21. Jan. 2016.

[35] Gharibeh, M.Y., Al-Tawallbeh, G.M., Abboud, M.M., Radaideh, A., Alhader, A.A, and Khabour, O.F, "Correlation of plasma resistin with obesity and insulin resistance in type 2 diabetic patients,” Diabetes \& Metabolism, 36(6 Pt1). 443-449. Dec. 2010.

[36] Jiang, Y., Lu, L., Hu, Y., Li, Q., An, C., Yu, X., Shu, L., Chen, A., Niu, C., Zhou, L, and Yang, Z, "Resistin induces hypertension and insulin resistance in mice via a TLR4-dependent pathway," Scientific Reports, 6. 22193. Feb. 2016.

[37] Kadowaki, T., Yamauchi, T., Kubota, N., Hara, K., Ueki, K, and Tobe, K, "Adiponectin and adiponectin receptors in insulin resistance, diabetes, and the metabolic syndrome," Journal of Clinical Investigation, 116(7). 1784-1792. Jul. 2006.

[38] Wang, H, and Eckel, R.H, "Lipoprotein lipase: from gene to obesity," American Journal of Physiology- Endocrinology and Metabolism, 297(2). E271-288. Aug. 2009.

[39] Havel, P.J, "Role of adipose tissue in body-weight regulation: mechanisms regulating leptin production and energy balance," Proceedings of the Nutrition Society, 59(3). 359-371. Aug. 2000.

[40] McManus, B.L., Korpela, R., Speakman, J.R., Cryan, J.F., Cotter, P.D, and Nilaweera, K.N, "Bovine serum albumin as the dominant form of dietary protein reduces subcutaneous fat mass, plasma leptin and plasma corticosterone in high fat-fed C57/BL6J mice," British Journal of Nutrition, 114(4). 654-662. Aug. 2015.

[41] Clarke, S.D, "Regulation of fatty acid synthase gene expression: an approach for reducing fat accumulation,” Journal of Animal Science, 71(7). 1957-1965. Jul. 1993.

[42] Frayn, K.N., Fielding, B.A, and Karpe, F, "Adipose tissue fatty acid metabolism and cardiovascular disease," Current Opinion in Lipidology, 16(4). 409-415. Aug. 2005.

[43] Gan, L., Liu, Z., Cao, W., Zhang, Z, and Sun, C, “FABP4 reversed the regulation of leptin on mitochondrial fatty acid oxidation in mice adipocytes,” Scientific Reports, 5. 13588. Aug. 2015.

\section{Supplementary Information}

Supplementary Table S1. PCR amplification conditions for gene expression analysis.

\begin{tabular}{|c|c|c|c|c|c|}
\hline Primer & $\begin{array}{l}\text { Sequence } \\
\left(5^{\prime}-3^{\prime}\right)\end{array}$ & $\begin{array}{l}\text { Amplicon } \\
\text { size (pb) }\end{array}$ & $\begin{array}{c}\text { Annealing } \\
\left({ }^{\circ} \mathrm{C}\right)\end{array}$ & Cycles & cDNA (ng) \\
\hline Lep $\mathrm{F}$ & ACATTTCACACACGCAGTCGG & \multirow{2}{*}{371} & \multirow{2}{*}{58.3} & \multirow{2}{*}{30} & \multirow[b]{2}{*}{800} \\
\hline Lep $\mathrm{R}$ & GCATTCAGGGCTAACATCCAAC & & & & \\
\hline Res $\mathrm{F}$ & СССТССТTТTССТTТTСТTССТTG & \multirow{2}{*}{251} & \multirow{2}{*}{56.8} & \multirow{2}{*}{30} & \multirow{2}{*}{150} \\
\hline Res $\mathrm{R}$ & TTCTTCACGAATGTCCCACGAG & & & & \\
\hline $\operatorname{Tnf}-\alpha \mathrm{F}$ & AAAGATGGGGGGCTTCCAGAACTC & \multirow{2}{*}{434} & \multirow{2}{*}{58.9} & \multirow{2}{*}{30} & \multirow{2}{*}{150} \\
\hline $\operatorname{Tnf}-\alpha \mathrm{R}$ & AGATAGCAAATCGGCTGACGG & & & & \\
\hline Lpl F & CCACTTCAACCACAGCAGCAAG & \multirow{2}{*}{412} & \multirow{2}{*}{57.8} & \multirow{2}{*}{30} & \multirow{2}{*}{150} \\
\hline Lpl R & ATCAGCGTCATCAGGAGAAAGGCG & & & & \\
\hline Fasn $\mathrm{F}$ & CCAATACAGATGGCAGCAAGGAG & \multirow{2}{*}{744} & \multirow{2}{*}{60} & \multirow{2}{*}{32} & \multirow{2}{*}{150} \\
\hline Fasn R & TCCCTGAGCAGATGAACCAGAGTG & & & & \\
\hline Fabp4 F & CAAGCCCAACATGATCATCAGC & \multirow{2}{*}{97} & \multirow{2}{*}{58.1} & \multirow{2}{*}{30} & \multirow{2}{*}{150} \\
\hline Fabp4 R & CACGCCCAGTTTGAAGGAAATC & & & & \\
\hline Adpn $\mathrm{F}$ & AAGGACAAGGCCGTTCTCT & \multirow{2}{*}{219} & \multirow{2}{*}{60} & \multirow{2}{*}{30} & \multirow{2}{*}{150} \\
\hline Adpn $\mathrm{R}$ & TATGGGTAGTTGCAGTCAGTTGG & & & & \\
\hline *18s F & GATCCATTGGAGGGCAAGTCT & \multirow{2}{*}{79} & \multirow{2}{*}{52} & \multirow{2}{*}{30} & \multirow{2}{*}{150} \\
\hline *18s R & AACTGCAGCAACTTTAATATACGCTATT & & & & \\
\hline
\end{tabular}

F=forward; R=reverse; Res=resistin; $L p l=$ lipoprotein lipase, Fabp4=fatty acid binding protein 4, Fasn=fatty acid synthase, Adpn=adiponectin, $18 S=18 \mathrm{~S}$ ribosomal. *Constitutive gene.

Supplementary Table S2. Factor loading for the five principal components

\begin{tabular}{|c|c|c|c|c|c|}
\hline & F1 & $\mathbf{F} 2$ & F3 & F4 & F5 \\
\hline \multicolumn{6}{|l|}{ Biochemical parameter } \\
\hline Weight difference (\%) & 0.917 & -0.123 & 0.148 & 0.314 & 0.154 \\
\hline Adipose tissue (g) & 0.874 & -0.119 & 0.019 & 0.471 & -0.027 \\
\hline Cholesterol (mg/dL) & 0.838 & 0.402 & -0.229 & -0.065 & 0.283 \\
\hline Triglycerides (mg/dL) & 0.682 & 0.615 & 0.351 & -0.084 & 0.161 \\
\hline Glucose (mg/dL) & 0.851 & -0.301 & -0.049 & 0.412 & -0.117 \\
\hline Insulin (ng/mL) & 0.124 & 0.571 & 0.792 & 0.027 & -0.173 \\
\hline \multicolumn{6}{|l|}{ Gene expression } \\
\hline Adpn & 0.840 & 0.424 & -0.298 & -0.098 & -0.126 \\
\hline Fabp4 & 0.752 & -0.572 & 0.237 & -0.223 & 0.030 \\
\hline Lep & 0.730 & -0.565 & 0.262 & -0.271 & 0.068 \\
\hline Lpl & 0.809 & 0.475 & -0.300 & -0.080 & -0.156 \\
\hline Res & 0.959 & 0.097 & -0.147 & -0.214 & -0.064 \\
\hline Tnf- $\alpha$ & 0.871 & -0.395 & 0.009 & -0.256 & -0.141 \\
\hline
\end{tabular}

Values in bold correspond for each variable to the factor for which the loading is the highest. 
Supplementary Table S3. Correlation coefficients between the gene expression in adipose tissue with physiological and biochemical parameters in the treated mice

\begin{tabular}{ccccccc}
\hline Variables & Weight difference $(\%)$ & Adipose tissue $(\mathrm{g})$ & Cholesterol $(\mathrm{mg} / \mathrm{dL})$ & Triglycerides $(\mathrm{mg} / \mathrm{dL})$ & Glucose $(\mathrm{mg} / \mathrm{dL})$ & $\mathrm{Insulin}(\mathrm{ng} / \mathrm{mL})$ \\
\hline Adpn & 0.623 & 0.635 & $\mathbf{0 . 9 1 3}$ & 0.717 & 0.576 & 0.129 \\
Fabp4 & 0.730 & 0.624 & 0.369 & 0.268 & 0.705 & -0.056 \\
Lep & 0.704 & 0.581 & 0.362 & 0.276 & 0.659 & -0.044 \\
Lpl & 0.589 & 0.611 & $\mathbf{0 . 8 9 8}$ & 0.721 & 0.545 & 0.159 \\
Res & 0.768 & 0.724 & $\mathbf{0 . 8 7 2}$ & 0.670 & 0.713 & 0.063 \\
Tnf- $\alpha$ & 0.746 & 0.691 & 0.546 & 0.354 & 0.771 & -0.093 \\
\hline
\end{tabular}

Values in bold show significant correlation $(p<0.05)$.

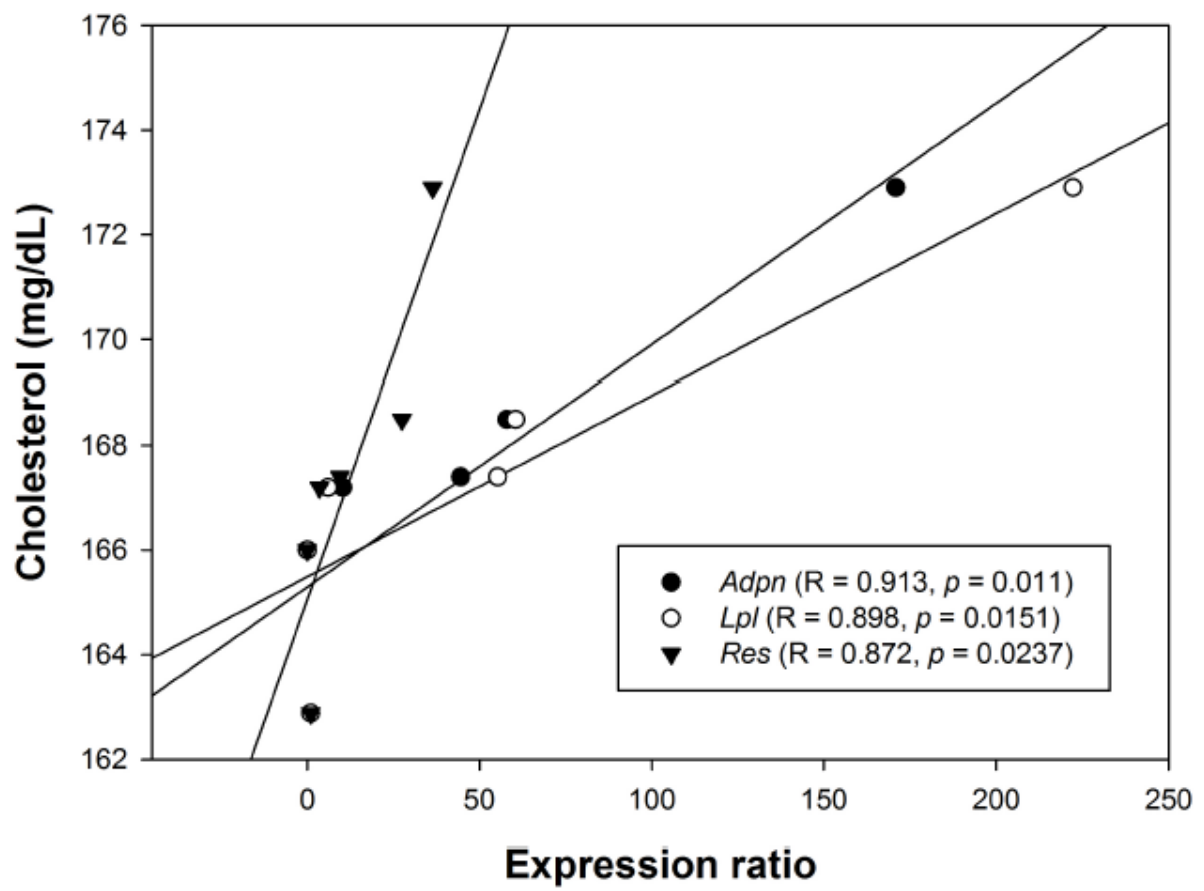

Supplementary Figure S1. Plot of the significant correlations between the gene expression of Adpn, Lpl and Res, and the cholesterol levels of the treated groups. $\mathrm{R}=$ Pearson's correlation coefficient, $p=p$ value. 